\title{
The forms of cooperation with the school community in Kosovo's schools
}

\author{
Adem Dreshaj", Hysen Muzlijaj, Hidajete Nikqi, Fidan Feka \\ Public University, "Hazhi Zeka” Peja
}

Email address:

ademdreshaj@hotmail.com (A. Dreshaj)

\section{To cite this article:}

Adem Dreshaj, Hysen Muzlijaj, Hidajete Nikqi, Fidan Feka, The Forms of Cooperation with the School Community in Kosovo's Schools. International Journal of Secondary Education. Vol. 1, No. 4, 2013, pp. 14-17. doi: 10.11648/j.jjsedu.20130104.11

\begin{abstract}
Education is a significant thing that everyone has to attain. Education is a process designed to instruct and educate the student in terms of physical, intellectual, and moral, aspect. The process and the result of educative work in schools are influenced by a large number of factors that affect the education directly and indirectly. These can be objective and subjective factors which are studied and presented in pedagogical, psychological, didactic- literature and recently studied and by other sciences such as medicine, sociology, etc. The most important factors of this material are teachers, students, parents, experts, school facilities, the material of teaching, textbooks, plan of teaching, teaching methods etc. The theory and practice of all above mentioned factors have a positive effect on the quality of educational process. These factors have to be organized to act in a mutual and reciprocal partnership during all school year and education rate.
\end{abstract}

Keywords: Collaboration, Community, Parents, Pupils, Schools, Istog

\section{Introduction}

The family as a very important factor is a changing historical category. It is formed and evolved during the formation and evolution of private property. Also it is affirmed as a social group which changes and evolves under the influence of various factors.

Education is essential and existential attribute of person and society. It is developed through the school society in different periods, starting from the first primitive community, the slave period, feudal, bourgeois society to contemporary society.

Due to the development of society and its change during different periods and industrial development, the need for the school as an institution that meets the needs and interests of human society was essential. School was the temple of knowledge during all social formations and during the development of science. It served certain interests of the society and the state in general. So now the school is an educational institution and the evolution of the society cannot be imagined without it, so it is given a special treatment by the developed and civilized nations.

Together with the teaching staff of these schools we have to try to preserve the good tradition of the schools, by creating a good image of cooperation. This good cooperation influences the teaching process by creating a good climate of respect for students, teachers, parents etc.

The objectives cannot be realized without a good cooperation between teachers - students -parents.

The problem that arises today is to increase the quality of teaching and education in schools, where the key role is, training and qualifying teachers, especially younger ones. The aim is to create a generation of more knowledgeable and skilled teachers, who could cope with the demands of time and modern technology. Education is a field which is associated with the interests of everyone. There is no family without children in school, it is said "Education belongs to all of us."

\subsection{The Object of Research}

The object of research is concerned with teacher-student -family partnership in high school in the municipality of Istog as indispensable mechanism in the establishment and development of educational process in the new conditions and circumstances such as economic, political, social, cultural, technological challenges and global reality. The research will also be focused on the research process in lower secondary schools, how it is working teacherstudent- family collaboration in a region not enough explored such is the municipality of Istog. 


\subsection{The Purpose of the Research}

The purpose of this research is to study these three very important factors for school and society, then to have results for these three factors as accurate as possible, for the progress of education in the country as it was in the past, how it is now in the present and how it is going to be in the future.

\subsection{Research Tasks}

Our tasks will be: the scientific research, pedagogical literature, psychological, didactic and other sciences literature that will help us to gain knowledge, skills, values and more competences in the field of education and modern education. The research will be based on qualitative and quantitative methods and techniques in order to extract accurate information of great value for the future of our school.

Our task is to examine this issue in lower secondary schools in the municipality of Istog as: 1. Teacher, 2. Student, 3. Management staff of lower secondary schools in the municipality, 4. Family and other factors that are in partnership of education and function of education 5.DKA-in

6. Other factors feature which affect the learning process. Then we will research entire literature that would explain these essential factors, we will research and study pedagogical documentation that possess these schools and MED, the organization a survey of population of teachers, students, parents, principals and education officials.

\section{The Cooperation of School and the Family Based on Traditional School}

Cooperation between school and family based on this traditional philosophy is closed, dysfunctional among the factors that has serious consequences for all educational factors : The interests and cooperation of school and family are not in harmony with each other, it is present the lack of cooperation between school-parents or family, the lack of initiatives, the lack of the will of organizers of the school staff, the work of teachers is not considered in terms of quality teachers, teaching theoretical knowledge is not based in practice also which is a big problem in and they are not related in everyday life. all above mentioned things affect the learning process, and they lead in an undeveloped society with problems of different nature. Aching does not prepare students for competition and changes in the labor market. School effectiveness is in risk to lose the moral and legal belief of function,

Parent-student cooperation increases against teachers and management staff of other negative phenomena.

As you can see, this student-teacher and family collaboration is very old and is accompanied by a lot of problems. For this reason the education system should be prepared for changes and they need to be quick changes and very tough changes.

\section{Teachers' Cooperation with Parents}

1) Good 46 or $45.54 \%$. 2) Approximately good 50 or $49.50 \% 3$ ) Not good 5 or $4.95 \%$. 4) Not cooperative at 0 or $0 \%$.

Based on the statement presented above we can say that 46 or $45.54 \%$ think the cooperation is good, 50 or $49.50 \%$ have declared approximately good and 5 or $4.95 \%$ are declared that school -parents cooperation is realized: 1 . According to the old forms 10 or $9.90 \%$

2. According to contemporary philosophy 33 or $32.67 \%$, 3. According to the combination of these two forms 58 or $57.42 \%$. Of 101 respondents 10 or $9.90 \%$ of these believe that the cooperation of school with parents is realized under the old forms, 33 or $32.67 \%$ according to contemporary philosophy and 58 or $57.42 \%$ think the combination of the two forms.

Traditional collaboration between school-family 1 . Enhances the learning process results in 88 or $87.12 \%$. 2 . Reduce the quality of the process of teaching 8 or $7.92 \% .3$. Not affect teaching in the position 5 or 88 or $4.95 \% 87.12 \%$ think that it increases learning process, reduce the quality of the process of teaching or $7.92 \% 8$ declared and 5 or $4.95 \%$ of them believe not affect the quality of teaching traditional form school-family collaboration

Cooperation between school and family are the successful ones. Individual contacts 22 or 17:18. \% 2 . parents visits in school 65 or $50.78 \% 3$. Meetings of parents 37 or $28.90 \% 4$. Visits of teachers in family 4 or $3: 12$ or $17: 18 \% 22 . \%$ Of them think that individual contacts have success in the form of cooperation between school and family, 65 or $50.78 \%$ think school visits, 37 or $28.90 \%$ of parents think the meeting and $3: 12$ or $4 \%$ of their teachers think through family visits.

How are elective courses selected from learners 1 . According to the learner and parent 39 or $39.39 \%$. 2 . According to learners will 0se $3939.39 \% 3$. According to teachers will $21: 21-21$ or $39 \%$ From 99 responses or $39.39 \%$ of them stated that the selection of elective subjects is conducted in cooperation pupil- parent teacher, 39 or $39.39 \%$ of the students stated that optional subject is conducted according to pupils will, and or 21:21 and 21\% stated according to teachers will

Indirect communication with parents 1 . With phone 76 or $66.08 \%, 2$. $23: 47$, paperwork or $27 \%, 3$. Internet 11 or $9: 56 \%, 4$. Not communicate at all with these forms or means 1 or $0.86 \%$

In response to this question took part 115 respondents, 76 of them think or $66.08 \%$, or $2723: 47$ paperwork $\%$ Internet $11 \%$ or $9: 56$, they do not communicate at all with these forms or means 1 or $0.86 \%$.

How does school -pupil- family impact teaching success in school 1. Raise the quality of teaching work 20 or $95.23 \%, 2$. There is little impact on the learning process in school 1 or $4.76,3$. There is no effect for school 0 or $0 \%$ from 21 Directors 20 or $95.23 \%$ considered that schoolfamily collaboration increase teaching quality in work, and 
has little impact on the learning process in school 1 or $4.76 \%$.

The cooperation between school and the family, 1 . Cooperation is a good 7 or $33.33,2$. Cooperation is not how much it is needed 14 or $66.66 \%, 3$. Cooperation does not meet the needs of School-family 0 or $0 \%$ from This question we took these answers: 32,10 or $31.25 \%$ think this collaboration is individual, parent meetings 14 or $43.75 \%$, the cooperation between school and family, 7 or $33.33 \%$ think cooperation is good tgood and necessary 14 or $66.66 \%$ think cooperation is not as good as it should be.

The cooperation of school and the family is realized by: 1. traditional philosophy 3 or $10: 34,2$. According to the philosophy "in the centre - learners" 7 or $24.13 \%, 3$. According to two philosophies, traditional and contemporary $10 \%$ or $3: 44,4$. Cooperation between school and family is not possible or $31.03 \% 9$. In this question the answer given were: 29 or 10:34 3\% think the cooperation is traditional, the philosophy "in the centre- learners" 7 or $24.13 \%$, according to two philosophies, traditional and contemporary $10 \%$ or $3: 44$ and school-family collaboration is not realized think 9 or $31.03 \%$ of respondents.

Forms of cooperation between school family - parents visits 8 or $25 \%$ teachers visits in family 0 or $0 \%$.

Education is the main basis for the development of an individual and of society in overall. It is related and with other factors, as are family, students, teachers. A good cooperation between them provides a better development of teaching process.

Our research started in schools as a planned organized factor for education of students organized in different historical periods up to the present time. So school was always related to prepare students, giving them more knowledge, skills and other virtues, to prepare them for a better life.

Contemporary Schools have changed significantly their approach to students, learning, technology, knowledge about health care, family cooperation, and the preparation of teachers' staff.

With the passing of time schools are better understood as key factor for the development of society.

As a factor in function of education we have treated in this research paper, teachers, students and family, that are in direct function of raising the quality of learning. The cooperation of these factors is explained and explored in this research paper and it is confirmed the hypothesis that genuine cooperation between pupil-teacher -family raisies educational quality.

We also clarify the forms of family-school collaboration and research results are shown with the statistical data, charts, it is also shown the differences and similarities between secondary schools in urban and rural lower secondary schools of Istog

It is worth mentioning that for this research paper have contributed many master university friends, my professor and mentor Dr. Jonuz Dervodelli, directors, parents, MED official, whom I would like to thank.

\section{Recommendation}

From this research in urban and rural schools in the municipality of Istog we reached the conclusion that the cooperation of school with family and other factors, positively affect the education and teaching, so we think that these schools must change, so we give some recommendations:

1. Schools must be ready to adapt to contemporary changes which will improve learning process,

2. Teacher-student collaboration has to be better, by elaborating methodological changes in the learning process,

3. Cooperation between school and family must raise in a higher level and understanding this necessity should be present,

4. Cooperation between school and family to be achieved under the new reforms, according to the Pre-University Curriculum Framework of Kosovo.

5. School management staff to be prepared with adequate trainings according to modern management, because there is still the traditional management which leads in low results,

6. The application of modern teaching methods in teaching is essential,

7. Planning and giving instructions to parents in order to help students at home,

8. Forming of pedagogical-psychological services in all schools,

9. Greater cooperation between Parent Council at school,

10. Better communication between school and family as meeting them at school using internet, phone, paperwork etc..

11. Taking advice from medical Doctors for pupils health

12. Applying additional supplementary work for pupils and organizing leisure activities in schools where conditions are present.

These recommendations are also given by teachers, parents, principals, MED official and from us as researchers of this research papers.

\section{References}

[1] A.SH.SH. 2002. Albanian dictionary today, Tirana.

[2] Academy of Sciences of Albania, Tirana, 2005.

[3] The school, challenges, achievements and aspirations, Pristina.

[4] Bekteshi dr.Bektesh.2009. students with lessons in the School. Pristina: Gafoprint.

[5] Bekteshi dr.Bektesh. Open 1970. Paper parents, "For parents" nr.2.Prishtinë.

[6] Berisha Beqir.1978. parents contributes to solving the difficulties: spark, Pristina.

[7] Bojaxhiu Aleksander.2004. Discipline in class learning for students and teachers. 
[8] Brada, Riza. Family 1995.Pedagogia as pedagogical discipline, Peja Dukadjini.

[9] Brada, Riza. 2003.Pedagogjia family, Peja Dukadjini.

[10] Buci, Mevlud. In 2011. School "Murat Toptani" Tirana. Teacher, number 9

[11] Citta the Cittadinanze, Progetto Domani. Solidarietà 2009.Cultura of Training The exchange between Italy and Kosovo in partnership for development, Rome:

[12] CRS printer. Charles Temple. 2001.Të critical thinking along the Curriculum, Open Society Institute, New York.

[13] Çitaku dr.Nezir. 2011.primary school Skenderaj century. XX: Ulcinj: IVPE Cetina

[14] Domani, Progeto.-Maria, Annan. 2009.Formimi through
Italy-Kosovo exchange for an interaction development.

[15] Dervodelli, Mr.Jonuz.1997.Informimi and professional orientation. Pristina: "Etruria"

[16] Dervodelli, dr.Jonuz.2010.

[17] Fullan, Majkell.2000 new educational change. Soros

[18] Gashi, Abdurrahim. 2005.Shkëndija, Pristina, June.

[19] Garo, Sofokli.2002.Sfidat of mësimdhënies.Tiranë.

[20] Group author, Shimlesha, dr.Pero. (Red) 1983.Pedagogjia.Prishtinë.

[21] Group of School 2001.Roli in parental involvement in education. Tirana. Aurora Group, (Red.S.Patak). 1964.Pedagogjia, Zagreb. 